\title{
A rare cause of oesophageal pigmentation
}

\author{
A Chattree, ${ }^{1}$ A Howat, ${ }^{2}$ A T Green, ${ }^{1}$ R Saravanan ${ }^{3}$ \\ ${ }^{1}$ Department of Gastroenterology, Royal Blackburn Hospital, East Lancashire Hospitals NHS Trust, Blackburn, UK \\ ${ }^{2}$ Department of Pathology, Royal Blackburn Hospital, East Lancashire Hospitals NHS Trust, Blackburn, UK \\ ${ }^{3}$ Department of Gastroenterology, Macclesfield District General Hospital, Macclesfield, UK
}

Correspondence to A Chattree, amitchattree@hotmail.com

\section{DESCRIPTION}

A 53-year-old woman was referred to gastroenterology with a 3-week history of dyspepsia and fatigue. She had no prior history of reflux symptoms, altered bowel habit or weight loss. There was no significant medical history and no history of alcohol or tobacco consumption. Physical examination was normal, and initial blood tests revealed a haemoglobin of $9.9 \mathrm{~g} / \mathrm{dl}$ and a ferritin of $18 \mu \mathrm{g} / \mathrm{l}$, consistent with iron-deficiency anaemia. An oesophagogastroduodenoscopy was performed and a linear blue/black pigmented macular lesion was noted in the oesophagus at $28 \mathrm{~cm}$, from which multiple biopsies were taken, in addition to oesophagitis (figure 1). Histopathology of the oesophageal biopsies showed squamous mucosa, with an increase in melanocytosis and dendritic processes spreading around adjacent epidermal cells, consistent with a diagnosis of oesophageal melanocytosis (figure 2). Differential diagnosis includes benign nevi, blue naevus and primary malignant melanoma because melanin deposition is often the main feature in these lesions. ${ }^{1}$ Addison's disease, anal melanoma and Laugier-Hunziker syndrome may also explain pigmented lesions found at endoscopy. ${ }^{12}$ Some authors have suggested oesophageal melanocytosis to be a precursor for oesophageal melanoma and carcinoma. ${ }^{3}$ Oesophageal melanocytosis is rare and is a histological diagnosis. Our case is the first from the UK to be considered for publication, and there are currently no follow-up studies to establish guidelines for management, including surveillance. We opted to commence the subject on a proton-pump inhibitor, with follow-up endoscopy within 18 months. Recognition of this lesion at endoscopy is vital, given the potential differential diagnoses.

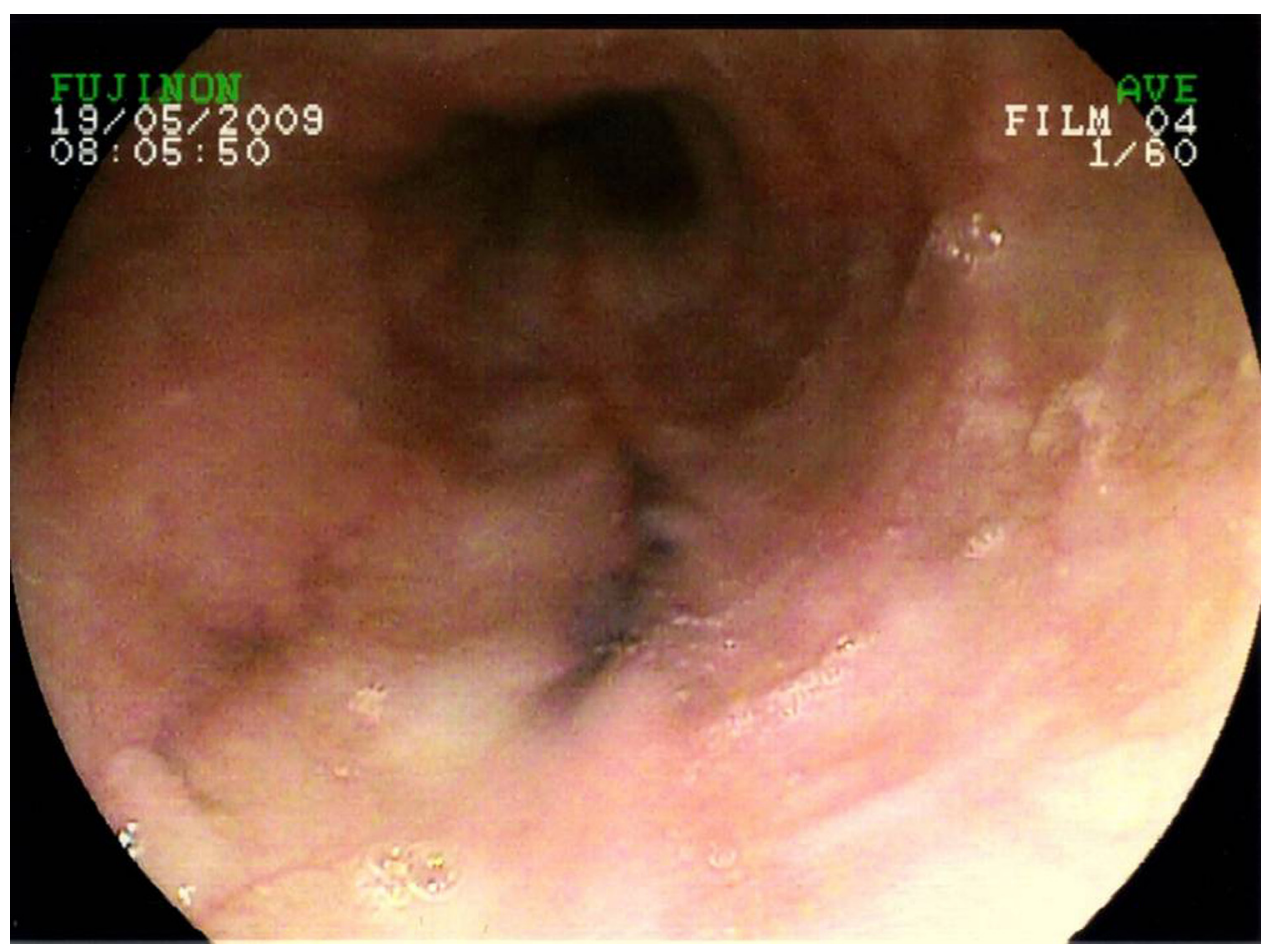

Figure 1 Endoscopic view of the oesophagus at $28 \mathrm{~cm}$. 


\section{BMJ Case Reports}

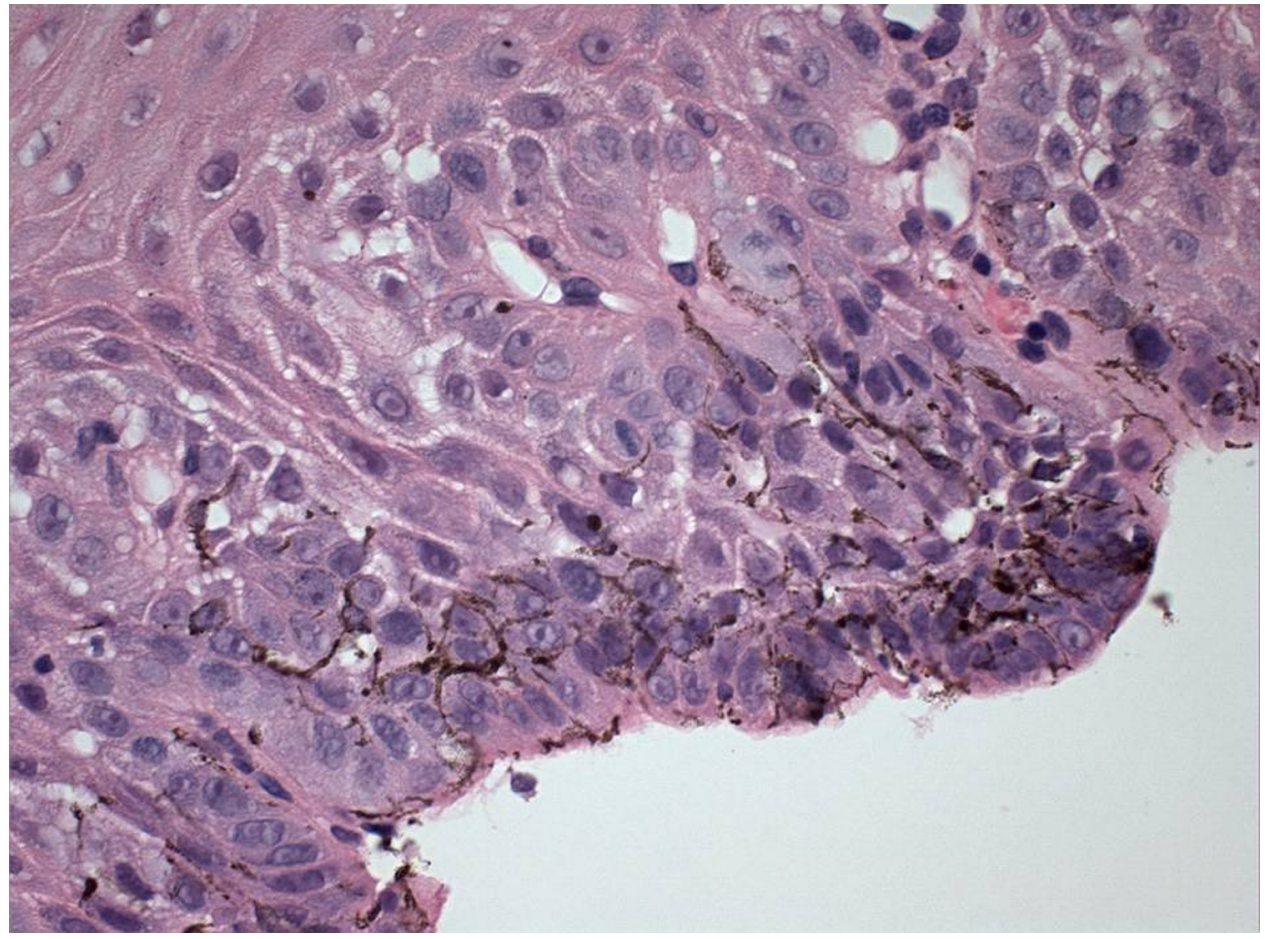

Figure 2 Histopathology of the oesophageal mucosal lesion.

Competing interests None.

Patient consent Obtained.

\section{REFERENCES}

1. Chang $\mathbf{F}$, Deere $\mathbf{H}$. Esophageal melanocytosis morphologic features and review of the literature. Arch Pathol Lab Med 2006:130:552-7.
2. Kanavaros $\mathbf{P}$, Galian $A$, Périac $P$, et al. [Primary malignant melanoma of the esophagus arising in melanosis. Histological, immunohistochemical and ultrastructural study of a case]. Ann Pathol 1989:9:57-61.

3. Yokoyama A, Omori T, Yokoyama T, et al. Esophageal melanosis, an endoscopic finding associated with squamous cell neoplasms of the upper aerodigestive tract, and inactive aldehyde dehydrogenase- 2 in alcoholic Japanese men. J Gastroenterol 2005;40:676-84.

\footnotetext{
This pdf has been created automatically from the final edited text and images.

Copyright 2010 BMJ Publishing Group. All rights reserved. For permission to reuse any of this content visit http://group.bmi.com/group/rights-licensing/permissions.

BMJ Case Report Fellows may re-use this article for personal use and teaching without any further permission.

Please cite this article as follows (you will need to access the article online to obtain the date of publication).

Chattree A, Howat A, Green AT, Saravanan R. A rare cause of oesophageal pigmentation. BMJ Case Reports 2010;10.1136/bcr.03.2010.2816, date of publication

Become a Fellow of BMJ Case Reports today and you can:

Submit as many cases as you like

Enjoy fast sympathetic peer review and rapid publication of accepted articles

- Access all the published articles

- Re-use any of the published material for personal use and teaching without further permission

For information on Institutional Fellowships contact consortiasales@bmjgroup.com

Visit casereports.bmj.com for more articles like this and to become a Fellow
} 